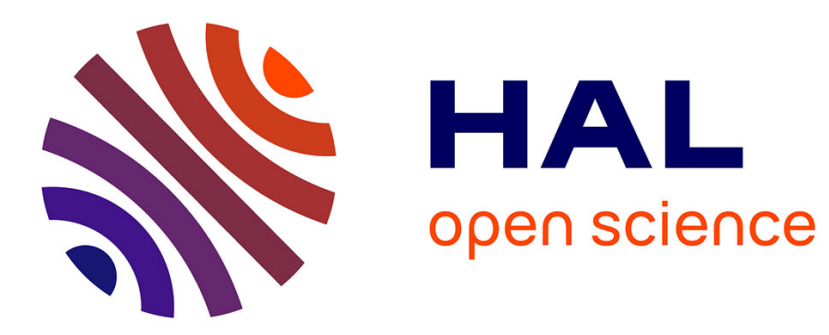

\title{
CORPORATE CASH HOLDING AND FIRM VALUE
}

Cristina Martinez-Sola, Pedro J Garcia-Teruel, Pedro Martinez-Solano

\section{To cite this version:}

Cristina Martinez-Sola, Pedro J Garcia-Teruel, Pedro Martinez-Solano.

CORPORATE

CASH HOLDING AND FIRM VALUE. Applied Economics, 2011, 45 (02), pp.161-170. 10.1080/00036846.2011.595696 . hal-00732524

\section{HAL Id: hal-00732524 \\ https://hal.science/hal-00732524}

Submitted on 15 Sep 2012

HAL is a multi-disciplinary open access archive for the deposit and dissemination of scientific research documents, whether they are published or not. The documents may come from teaching and research institutions in France or abroad, or from public or private research centers.
L'archive ouverte pluridisciplinaire HAL, est destinée au dépôt et à la diffusion de documents scientifiques de niveau recherche, publiés ou non, émanant des établissements d'enseignement et de recherche français ou étrangers, des laboratoires publics ou privés. 


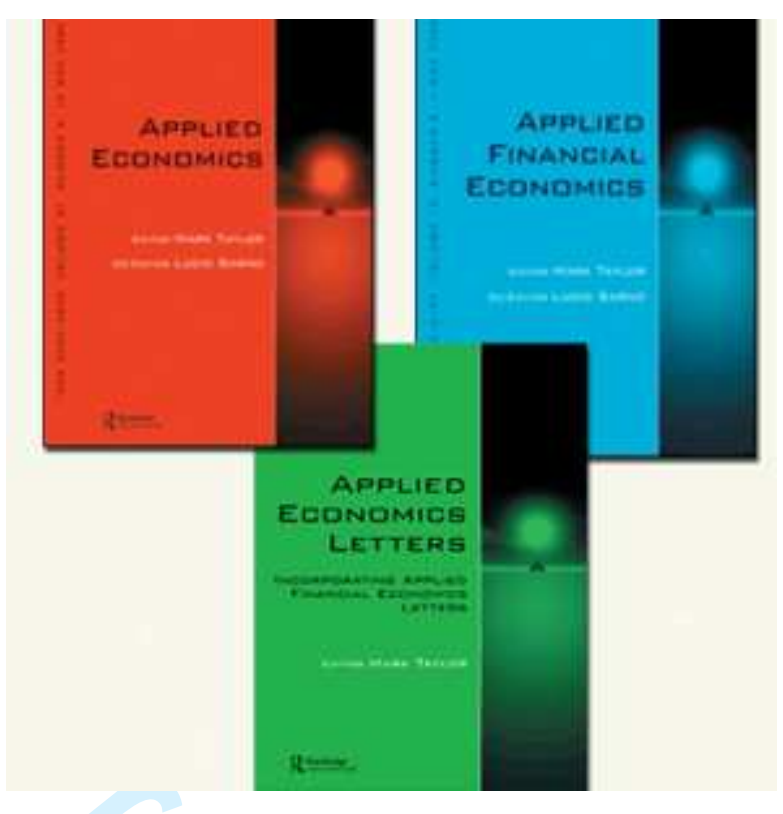

\section{CORPORATE CASH HOLDING AND FIRM VALUE}

\begin{tabular}{|c|c|}
\hline Journal: & Applied Economics \\
\hline Manuscript ID: & APE-2010-0550 \\
\hline Journal Selection: & Applied Economics \\
\hline $\begin{array}{r}\text { Date Submitted by the } \\
\text { Author: }\end{array}$ & 10-Dec-2010 \\
\hline Complete List of Authors: & $\begin{array}{l}\text { MARTINEZ-SOLA, CRISTINA; UNIVERSITY OF JAEN, ACCOUNTING } \\
\text { AND FINANCE } \\
\text { GARCIA-TERUEL, PEDRO; UNIVERSITY OF MURCIA, MANAGEMENT } \\
\text { AND FINANCE } \\
\text { MARTINEZ-SOLANO, PEDRO; UNIVERSITY OF MURCIA, } \\
\text { MANAGEMENT AND FINANCE }\end{array}$ \\
\hline JEL Code: & $\begin{array}{l}\text { G30 - General < G3 - Corporate Finance and Governance < G - } \\
\text { Financial Economics, G31 - Capital Budgeting|Investment Policy < } \\
\text { G3 - Corporate Finance and Governance }<\text { G - Financial Economics }\end{array}$ \\
\hline Keywords: & Cash holdings, firm value, asymmetric information \\
\hline
\end{tabular}

\section{SCHOLARONE ${ }^{m}$ \\ Manuscripts}




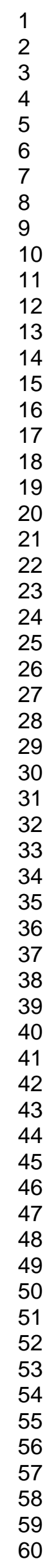

14

15

16

18

19

20

22

23

25

26

27

29

30

32

33

34

35

36

37

38

41

42

4

45

46

47

48

49

51

52

53

54

56

57

58

60

Editorial Office, Dept of Economics, Warwick University, Coventry CV4 7AL, UK 


\title{
CORPORATE CASH HOLDING AND FIRM VALUE
}

\begin{tabular}{|c|c|c|}
\hline Cristina Martínez-Sola & Pedro J. García-Teruel* & Pedro Martínez-Solano \\
Dep. Accounting and Finance & Dep. Management and Finance & Dep. Management and Finance \\
Faculty Social Sciences and Law & Faculty of Economics and & Faculty of Economics and \\
University of Jaén & Business & Business \\
Jaén (SPAIN) & University of Murcia & University of Murcia \\
Tel: +34 953 211957 & Murcia (SPAIN) & Murcia (SPAIN) \\
Fax: +34 953211869 & Tel: +34868887828 & Tel: +34 868883747 \\
E-mail: mmsola@ujaen.es & Fax: +34868887537 & Fax: +34868887537 \\
& E-mail: pjteruel@um.es & E-mail: pmsolano@um.es \\
\hline
\end{tabular}

\begin{abstract}
This study contrasts the effect of cash holding on firm value for a sample of US industrial firms during 2001-2007. The study tests empirically for the existence of an optimal cash level that maximizes firm value. Secondly, the study analyzes whether or not deviations from the optimum cash level reduce firm value. The results show a concave relation between cash holding and firm value, verifying the existence of an optimum level of cash holding. Additionally, and consistent with the initial analysis, deviations above and below optimal cash holding decrease firm value.
\end{abstract}

Keywords: Cash holdings, firm value, asymmetric information

JEL CLASSIFICATION: G30, G31

December 2010

* Corresponding author 


\section{INTRODUCTION}

Corporate cash holdings is receiving increasing attention in the finance literature. The special interest lies in the fact that corporations hold significant amounts of cash in their balance sheets. Specifically, Dittmar and Marth-Smith (2007) state that in 2003 the sum of all cash and marketable securities represented more than $13 \%$ of the sum of all assets for large publicly traded US firms. From another perspective, the aggregate cash held by publicly traded US firms in 2003 represents approximately $10 \%$ of annual US GDP. Consequently, the cash reserves of a firm are a relevant factor of study and one that affects firm's value. Liquidity management may therefore be a key issue for corporate policy.

The first studies to focus on this topic looked at antecedents of corporate cash holdings (Ferreira and Vilela, 2004; Garcia-Teruel and Martinez-Solano, 2008; Kim, Mauer, and Sherman, 1998; Opler, Pinkowitz, Stulz, and Williamson, 1999; Ozkan and Ozkan, 2004). Most of these papers assume that a target cash level exists; proving that cash decisions follow a partial adjustment model, though no empirical evidence justifies why firms follow a partial adjustment model.

Recent papers investigate the marginal value of cash from different perspectives. They study how valuable or necessary cash is by analyzing the increase in shareholder value associated with one additional dollar held by the firm, splitting the sample into subsamples according to firm-specific conditions. Specifically, Pinkowitz, Stulz and Williamson (2006) estimate the marginal value of cash and find that the relation between cash holdings and firm value is much weaker in countries with poor investor protection than in other countries. Dittmar and Marth-Smith (2007) investigate how 
corporate governance impacts on firm value by comparing the value and use of cash holdings in poorly and well-governed firms. Another group of studies links the value of cash to firm's investment opportunities (Pinkowitz and Williamson, 2007) or to corporate financial policies (Faulkender and Wang, 2006). Drobetz, Grüninger and Hirschvogl (2009) study the marginal value of cash in connection with firm-specific and time varying information asymmetry, obtaining that information asymmetry decreases the marginal value of cash. Finally, Tong (2009) studies the effect of firm diversification on the value of corporate cash holdings by employing the Faulkender and Wang (2006) methodology to measure the marginal value of cash holdings.

Despite the increasing amount of literature on corporate cash holding, no studies focus on the straight link-on effect of corporate cash holdings on firm value. Corporate cash holdings have benefits and costs for the firm and, consequently, an optimum cash level may exist at which the value of the firm is maximum.

The benefits of holding cash balances are several. First, for precautionary motives, firms maintain liquidity to meet unexpected contingencies, so firms hold cash to protect themselves against the likelihood of cash shortfalls, thus reducing cash flow uncertainty. For transactional motives, firms need liquidity to face their current expenses (Keynes, 1936). Finally, cash could prevent underinvestment costs. Internal funds enable firms to undertake their profitable investment projects without raising outside funds at high transaction costs. The existence of such benefits should make cash holdings valuable to shareholders. However, holding liquid assets implies an opportunity cost. Furthermore, corporate liquidity can cause agency problems between managers and shareholders. The free cash flow might increase discretion by managers, which goes against shareholders' interest (Jensen, 1986). 
Thus, a firm's optimum cash holding may be the outcome of a trade-off between the costs and the benefits of having liquid assets to derive an optimum cash level, as the Kim et al. (1998) model predicts. The firm balances the benefits of cash holdings against various costs of holding large cash reserves. The optimum cash level should be the point where marginal costs of cash just offset the marginal benefits.

This paper contributes to the literature by testing empirically if firms have an optimum cash level at which to maximize their value. The study first considers a nonlinear relationship (concave) between cash holdings and firm value. If a concave relation exists deviations from the inflexion point (maximum) will reduce firm value. This lead to the following question: Does firm value decrease if the level of cash moves away from its optimum level? The paper addresses this question following Tong's (2008), including the residuals of the optimum cash level regression. Using three different proxies for firm value means the results are robust.

This paper provides new evidence for the relationship between corporate cash holdings and firm value. The results show empirically that an optimum level of cash holdings exists at which firm value is maximum, for a sample of 472 listed US industrial companies during 2001-2007. Deviations from the optimum level reduce firm value.

The paper continuous as follows. Section 2 reviews corporate finance literature, focusing on cash and firm value literature. Section 3, gives a general description of the sample and variables employed. Section 4, describes the quadratic model linking cash holding and firm value, analyses the effect on firm value of the deviation from optimum 
cash holding level, and reports the results. The main conclusions and implications of the study conclude the paper.

\section{THEORETICAL FOUNDATIONS AND HYPOTHESIS}

According to Stiglitz (1974), in the absence of market imperfections, firms' financial decisions would not affect their value. In this theoretical situation, external finance is always readily available and at a reasonable price. The absence of a premium for liquidity or taxes would mean that keeping cash would have neither an opportunity cost nor fiscal disadvantages. So, keeping liquid financial assets would be irrelevant and decisions about investment in liquid assets would not affect shareholders' wealth (Opler, Pinkowitz, Stulz and Williamson, 2001). However, in practice, the irrelevance of cash does not hold. The existence of market imperfections implies a possible optimum cash level that balances costs and benefits and maximizes the value of the firm.

This suggests that firms trade off the costs and benefits of holdings cash to derive an optimum cash level. With regard to the benefits, firms need cash to meet the needs arising from normal activities, to take advantage of profitable future investment opportunities and to meet unforeseen events (transactional and precautionary motives). If capital market access were perfect, then regardless of the firm's liquidity, companies would always be able to fund positive net present value (NPV) projects. However, due to the presence of information asymmetry between creditors and debtors, obtaining external funding for firms is difficult and expensive because of problems relating to adverse selection. This can generate underinvestment problems because of the 
possibility that firms will choose not to issue, as they are not willing to issue undervaluated securities, and will therefore pass up a positive-NPV investment (Myers, 1977).

As access to capital becomes more difficult, forgoing positive NPV projects is more likely (Faulkender and Wang, 2006). Therefore, higher cash holdings increase the likelihood of taking value-enhancing projects that would otherwise be forgone; cash holdings could reduce the firm's dependence on costly external financing. As Keynes (1936) was the first to propose, a major advantage of having liquid assets in the balance sheet is that firms can undertake valuable projects when they arise. Additionally, corporate liquidity reduces the likelihood of incurring financial distress costs if the firm's operations do not generate sufficient cash flow to meet obligatory debt payments (Faulkender and Wang, 2006). According to precautionary motive, firms hoard cash to protect themselves against adverse cash flow shocks, thus avoiding liquidity constraints costs. Nevertheless, depending on the firm's characteristics, the costs of cash shortfalls or the costs of raising funds would differ. Firms for which these costs are higher might hold large cash reserves.

As for the negative aspects of holding cash, the financial literature identifies two main costs. On the one hand, holding liquid assets implies an opportunity cost, due to the lower return of these assets relative to other investments of the same risk, especially if the firm gives up more profitable investments to hold that level of cash. Dittmar, Mahrt-Smith, and Servaes (2003) refer to cost-of-carry as the difference between the return on cash and the interest that would arise to finance an additional dollar of cash. On the other hand, without wealth maximization, the benefit of corporate liquidity in undertaking projects without rising outside funds could turn into a cost, on account of 
the lack of monitoring by capital markets. Large cash reserves can increase agency conflicts between managers and shareholders, since managers can waste funds on inefficient investment which offers non-pecuniary benefits but which destroys shareholder value (Jensen and Meckling, 1976), or on their own pet projects. Following the free cash flow theory (Jensen, 1986), an overinvestment costs exists in those situations where cash facilitates investment in negative NPV projects. The existence of large free cash flow may also generate discretional behaviors in the managers that are harmful to shareholders' interests (Jensen, 1986), as increased managerial discretion could lead managers to squander corporate liquidity resources.

Consequently, the agency cost literature includes two confronting positions regarding cash balances. Myers and Majluf (1984) argue that firms optimally carry large cash balances to avoid having to raise outside capital because cash balances confer financial flexibility benefits but entail no agency costs. Meanwhile, Jensen (1986) proposes that firms optimally carry only minimal cash balances because excess cash balances entail agency costs but provide no flexibility benefits. For this reason, DeAngelo and DeAngelo (2007) consider that cash balances both entail agency costs and confer flexibility benefits and, thus, cash accumulation is no longer uniformly beneficial (as in Myers and Majluf, 1984) and investors will pressure firms to limit cash balances to mitigate agency costs, while also encouraging managers to maintain a cash cushion that is sufficient to fund moderate unanticipated capital needs that may arise.

A trade-off therefore may determine a firm's optimum cash holding between the costs and benefits of having liquid assets to derive an optimal cash level. However, the direct relationship between cash holding and firm value has not been the subject of studies to date. 
In order to fill that gap in the literature, this paper contrasts how the firm's cash holdings affect its value. The study estimates optimum cash holdings as the equilibrium between advantages and disadvantages of holding cash. According to the transactional motive and precautionary motive, cash is beneficial for firms. Firms need cash to carry out their normal activities, to take advantage of profitable future investment opportunities, and to meet unforeseen events. In contrast, the free cash flow theory postulates that cash holdings are detrimental for firms, since cash holdings imply agency costs (because managers have a large amount of funds under their control and they have more power). Thus, this study tests for two different effects of cash holding on firm value. On the one hand, at lower levels of cash, transaction and precautionary motives will predominate, and so an increase in cash levels is the precursor to increases in firm value. On the other hand, at higher levels of cash, the free cash flow and opportunity cost will predominate, and then an increase in cash levels is the forerunner to reductions in firm value. Thus, a non linear relationship (concave) between cash holdings and value of the firm is likely. The turning point will represent the maximum value of the company.

\section{DATA AND VARIABLES}

\section{Data}

Data from Balance sheets and Profit and Loss accounts come from the OSIRIS database. The study also uses US interest rates (short and long term debt), capital goods prices and the wholesale index. 
In line with papers like Kim et al. (1998), or Opler et al (2001), which employ a panel of US industrial firms to study determinants of cash holding, and Pinkowitz and Williamson (2001), who use a sample of industrial firms from US, Germany, and Japan to study the effect of bank power on cash holdings, this paper also uses a sample of industrial firms, specifically, publicly traded US firms belonging to the SIC Code from 3000 to 5999, during 2001 to 2007.

Information screening eliminated cases with errors in the accounting data or lost values for some of the variables from the sample. Firms with fewer than five consecutive observations did not form part of the sample. A necessary requisite was to perform the Hansen test. The result is an unbalanced panel comprising 472 companies, representing 3,055 firm-year observations. The study does not use a sample of balanced panel data in the analysis in order to avoid surveillance bias.

\section{Variables}

The dependent variable in the study is firm value. Tobin's $Q(Q)$ is a proxy for firm value. This is the ratio of the firm's market value to the replacement cost of its assets (Lewellen and Badrinath, 1997). Tobin's Q is common in corporate finance studies to measure firm valuation (Lin and Su, 2008; McConnell and Servaes 1990; McConnell, Servaes and Lins, 2008; Morck, Shleifer, and Vishny, 1988; Tong, 2008; among others). Tobin's Q is a proxy for corporate performance (Demsetz and Villalonga, 2001). Two additional proxies for firm value test the robustness of the results. First, Market-To-Book ratio 1 (MKBOOK1), defined as the ratio of market value of firm (market value of equity plus book value of total debt) to book value of firm (total assets) - this is the approximation for Tobin's Q that Chung and Pruitt (1994) suggest. Second, 
Market-To-Book ratio 2 (MKBOOK2), which is the ratio of market value of equity to book value of equity.

The key independent variable is $\mathrm{CASH}$, measured as cash and cash equivalent to total assets. According to the Federal Reserve System (FRS), cash equivalents are shortterm, highly liquid investments that are easy to convert into cash and that carry an insignificant risk of loss in value. $\mathrm{CASH}$ and its square $\left(\mathrm{CASH}^{2}\right)$ serve to test for the existence of a non linear model. A positive relationship between cash and firm value when cash level is below the optimal is likely, as is a negative association between cash and value above the optimal cash holding level, pointing to a positive sign for variable CASH and a negative one for $\mathrm{CASH}^{2}$.

The study also includes the control variables that McConnell and Servaes (1990), and Morck et al. (1988) consider as important determinants of Tobin's Q. These control variables include investment in intangible assets, firm size, and leverage. INTANGIBLE is the ratio of intangible assets to total assets and measures the extent to which firms invest in intangible capital, and is the proxy of growth opportunities. The size (SIZE) is the natural logarithm of gross sales. Finally, the leverage (LEV) is total debt divided by shareholder equity.

Table 1 presents descriptive statistics for the variables in this study. The data are from 2001 to 2007 , revealing that the mean cash ratio is $7.9 \%$ and the median is $4.48 \%$. These values are in line with the median values in Kim et al. (1998) in the same market (USA), 8.1\%, Ozkan and Ozkan (2004) in the UK, 9.9\%, and Garcia-Teruel and Martinez-Solano (2008) in Spain, 6.57\%.

\section{Table 1 here}


Note that ten per cent of firms in this sample have a very small ratio of cash. They hold less than one per cent of cash over total assets. Ten percent of firms hold more than twenty per cent of cash.

Important differences exist between the firm value proxies: the means of the variables $\mathrm{Q}$ and MKBOOK1 are above their median value, indicating a strong scattering towards the right tail, that is, some companies' values are much higher than the others; the variable MKBOOK2 observed is, however, the opposite. Also, the dispersion of MKBOOK2 is almost eight times higher than the other two variables. Therefore, the empirical distributions of these variables are very different. These divergences between these three proxies are one of the main reasons for including two additional different proxies to give robustness to the main results and to employ Tobin's Q as dependent variable.

\section{Table 2 here}

Table 2 presents the correlation matrix. No high correlations exists among the independent variables, which could lead to multi-colineality problems and, consequently, inconsistent estimations.

\section{CORPORATE CASH HOLDING AND FIRM VALUE}

In order to study if an optimum level of cash holding exists the authors estimate Model 1, where the market value in firm $\mathrm{i}$ at time $\mathrm{t}$ depends on cash holdings and its square. The inclusion of these two variables in the model tests both the transactional and 
precautionary motives for holding cash and the free cash flow theory and opportunity costs, as well as optimally determining the breakpoint of the value-cash relationship. As above, the study also controls for intangible assets, size, and leverage, as in McConnell and Servaes (1990) and Morck et al. (1988).

\section{Model 1:}

$\mathrm{V}_{\mathrm{it}}=\beta_{0}+\beta_{1}\left(\mathrm{CASH}_{\mathrm{it}}\right)+\beta_{2}\left(\mathrm{CASH}^{2}{ }_{\mathrm{it}}\right)+\beta_{3}\left(\mathrm{INTANGIBLE}_{\mathrm{it}}\right)+\beta_{4}\left(\mathrm{SIZE}_{\mathrm{it}}\right)+\beta_{5}\left(\mathrm{LEV}_{\mathrm{it}}\right)+$ $\eta_{\mathrm{i}}+\lambda_{\mathrm{t}}+\varepsilon_{\mathrm{it}}$

where the dependent variable $\left(\mathrm{V}_{\text {it }}\right)$ is the firm value, and the independent variables are $\mathrm{CASH}_{\mathrm{it}}$, which measures cash and cash equivalent to total assets holding by firm i at time $t$, INTANGIBLE $_{i t}$ which measure the growth opportunities, SIZE $_{i t}$ the size of the firms and LEV $V_{i t}$ the leverage. $\eta_{i}$ is the unobservable heterogeneity. The model measures both firms' particular characteristics and the characteristics of the sector in which they operate. $\lambda_{t}$ are dummy variables that change in time but are equal for all firms in each of the periods considered. In this way, dummy variables seek to capture the economic factors that firms cannot control and which may affect their value. $\varepsilon_{\mathrm{it}}$ is the error term.

Following Arellano and Bond (1991), the study uses the GMM method of estimation on the model in first differences, which controls for unobservable heterogeneity and prevents potential endogeneity problems. All estimations are with the two-step estimator, considering all variables as endogenous and employing the lagged independent variables as instrument. This is because firms are heterogeneous, and various factors will always be influencing firm value that are difficult to measure or hard to obtain (see Himmelberg, Hubbard, and Palia, 1999). Cash literature has often considered the endogeneity problem (e.g. Ozkan and Ozkan, 2004). 
This estimation assumes no second-order serial correlation in the errors in first differences. Thus, in order to test the consistency of the estimations, the study includes the test for the absence of second-order serial correlation by Arellano and Bond (1991). $m_{2}$ is test statistic for second order autocorrelations in residuals, distributed as standard normal $\mathrm{N}(0,1)$ under the null hypothesis of no serial correlation. The study also uses the Hansen test for over-identifying restrictions, which tests for the absence of correlation between the instruments and the error term.

Table 3 shows the results of the estimation of model 1 using three different proxies for firm value. In the first column the calculation of firm value is Tobin's Q (Q). In the second and third columns MKBOOK1 and MKBOOK2 are proxies for firm value respectively. Consistent with expectations, $\mathrm{CASH}$ is positive and statistically significant, while $\mathrm{CASH}^{2}$ is negative and significant at $1 \%$ level for the three different specifications of dependent variables. This means that cash holding increases the value of the firm up to the breakpoint, after which, increases in the cash holding reduces the firms value.

\section{Table 3 here}

The stability of the estimated coefficients for three different specifications of dependent variables demonstrates the robustness of the findings regarding the nonlinear relationship between cash holdings and firm value.

In accordance with control variables, LEV relates positively to the three proxies of firm value. Additionally, the coefficient of the variable SIZE is negative, but not always significant. Also, Demsetz and Villalonga (2001) report a non significant 


\section{Deviation from the optimal cash level}

A quadratic relation (concave) occurs between firm cash holdings and firm value, as a consequence of two contrary effects. This section provides evidence to give an additional support to the fact that firm value declines if firms move away from this optimum. Because of the costs associated with holding cash in excess (such as opportunity cost or agency costs), the market might not place a high value on such cash holdings above the optimum level.

However, the market will place a higher value on liquidity for those firms that are below the optimum cash holding level. Thus, the study analyzes the relation between deviations from optimal cash holdings and firm value. If a non-linear cashvalue relationship exists in the first study, where an optimal point which maximizes 
firm value exists, deviations from this optimal cash level will probably reduce firm value. Specifically, model 1 eliminates variable $\mathrm{CASH}$ and $\mathrm{CASH}^{2}$ and includes the residual estimated in the benchmark specification for antecedents of cash holdings as explanatory variable.

In order to do this, the study considers that benchmark specification for antecedents of cash holdings is according to the equation below, which has support in previous studies on antecedents of cash holdings (Kim et al., 1998; Garcia-Teruel and Martinez-Solano, 2008; Opler et al., 1999; and Ozkan and Ozkan, 2004).

Model 2:

$\mathrm{CASH}_{\mathrm{it}}=\beta_{0}+\beta_{1}\left(\mathrm{CFLOW}_{\mathrm{it}}\right)+\beta_{2}\left(\mathrm{LIQ}_{\mathrm{it}}\right)+\beta_{3}\left(\mathrm{LEV}_{\mathrm{it}}\right)+\beta_{4}\left(\mathrm{SIZE}_{\mathrm{it}}\right)+\beta_{5}\left(\mathrm{BANKD}_{\mathrm{it}}\right)+\beta_{6}$ $\left(\right.$ INTANGIBLE $\left._{\mathrm{it}}\right)+\eta_{\mathrm{i}}+\lambda_{\mathrm{t}}+\varepsilon_{\mathrm{it}}$

where $\mathrm{CASH}_{\mathrm{it}}$ is cash and cash equivalent to total assets; $\mathrm{CFLOW}_{\text {it }}$ is earnings after tax plus depreciation divided by gross sales; $\mathrm{LIQ}_{\mathrm{it}}$, proxy for liquid assets, is working capital less total cash and short term investment to total assets; $\mathrm{LEV}_{\mathrm{it}}$, leverage, is total liabilities and debt divided by shareholders' equity; SIZE $\mathrm{it}_{\mathrm{it}}$ is the size of the firm, BANKD $_{\text {it }}$ is the ratio of bank loans to total debt; and INTANGIBLE $E_{i t}$, proxy for growth opportunities, is intangible to total assets;. $\eta_{\mathrm{i}}$ is the unobservable heterogeneity. $\lambda_{\mathrm{t}}$ are time dummy variables and $\varepsilon_{i t}$ is the error term. Appendix A includes the estimation of model 2.

The next step is to obtain residuals from Model 2 and include these in model 1 after eliminating CASH and $\mathrm{CASH}^{2}$ (model 3). Thus, DEVIATION is the absolute value of 
these residuals. The aim is to find if deviations from the optimal cash level affects a firm's value, which estimation of the following model does.

\section{Model 3:}

$\mathrm{V}_{\mathrm{it}}=\beta_{0}+\beta_{1}\left(\right.$ DEVIATION $\left._{\mathrm{it}}\right)+\beta_{2}\left(\operatorname{INTANGIBLE}_{\mathrm{it}}\right)+\beta_{3}\left(\operatorname{SIZE}_{\mathrm{it}}\right)+\beta_{4}\left(\mathrm{LEV}_{\mathrm{it}}\right)+\eta_{\mathrm{i}}+\lambda_{\mathrm{t}}$ $+\varepsilon_{\mathrm{it}}$

where $\mathrm{V}_{\text {it }}$ is firm value, proxied as Tobin's $\mathrm{Q}$, MKBOOK1, and MKBOOK2. The main dependent variable is DEVIATION $\mathrm{it}_{\mathrm{it}}$, defined as the absolute value of residuals of equation 2, and INTANGIBLE $\mathrm{it}_{\mathrm{it}}, \mathrm{SIZE}_{\mathrm{it}}$, and $\mathrm{LEV}_{\mathrm{it}}$ are control variables defined as above.

$\beta_{1}<0$ is the expectation in Model 3, implying a negative relation between deviations from optimal cash holding level and firm value.

\section{Table 4 here}

Table 4 presents panel data regressions to explain whether deviations from optimum cash holding influence firm value (model 3) for three alternative measures of the firm value. In accordance with expectations, DEVIATION presents an inverse relationship with firm value, since its coefficient is negative and significant at $1 \%$. Results confirm the existence of a point that maximizes firm value, and as firms move away from this point so their value decreases. As before, the study proxies value as Tobin's Q, MKBOOK1 and MKBOOK2, and obtains the same results. However, this model does not distinguish whether these deviations are positive or negative. 
In order to analyze the way in which both deviations, above and below optimal cash level, affect firm value, model 4 includes an interaction term. So, the definition of the variable INTERACT is Above-optimal*DEVIATION. Above-Optimal is a dummy variable that takes 1 for positive residuals and 0 otherwise. Hence, the estimation of model 4, defined as:

Model 4:

$\mathrm{V}_{\mathrm{it}}=\beta_{0}+\beta_{1}\left(\right.$ DEVIATION $\left._{\mathrm{it}}\right)+\beta_{2}\left(\right.$ INTERACT $\left._{\mathrm{it}}\right)+\beta_{3}\left(\right.$ INTANGIBLE $\left._{\mathrm{it}}\right)+\beta_{4}\left(\mathrm{SIZE}_{\mathrm{it}}\right)+$ $\beta_{5}\left(\mathrm{LEV}_{\mathrm{it}}\right)+\eta_{\mathrm{i}}+\lambda_{\mathrm{t}}+\varepsilon_{\mathrm{it}}$

where $\mathrm{V}_{\mathrm{it}}$ is firm value, proxied as Tobin's $\mathrm{Q}$, MKBOOK1, and MKBOOK2. The main dependent variables are DEVIATION ${ }_{\mathrm{it}}$, absolute value of residuals, and INTERACT it $_{\text {. }}$ As in the previous model, control variables are INTANGIBLE ${ }_{i t}, S_{Z} E_{i t}$, and LEV it $_{\text {. }}$

How do variables DEVIATION (coefficient $\beta_{1}$ ) and DEVIATION + INTERACT (coefficients $\beta_{1}+\beta_{2}$ ) affect firm value? $\beta_{1}<0$ and $\beta_{1}+\beta_{2}<0$ is the expectation. This finding implies a negative effect of both above-optimal and belowoptimal deviations on firm value. In the case that residuals are positive, above-optimal variable takes the value 1 , and $\beta_{1}+\beta_{2}$ accounts for the effect on firm value. Otherwise, when residuals are negative, above-optimal variable takes the value 0 . Therefore INTERACT is zero, and $\beta_{1}$ accounts for the effect.

\section{Table 5 here}


As table 5 shows, DEVIATION is negative and statistically significant in all three cases. On the other hand, INTERACT is positively related to firm value in columns 1 and 2. As Tong (2008) points out, INTERACT could be positive since positive and negative residuals offset each other. However, the interest here is in the sum of the coefficients $\beta_{1}+\beta_{2}$. An $F$ test proves that $\beta_{1}+\beta_{2}$ remains negative and statistically significant. Indeed, the F-test reveals that the sum of these two coefficients is significant at higher than the $10 \%$ level. These results support the hypothesis that deviations on either side of optimal cash holding reduce firm value.

In column 3 Table 5, DEVIATION is once again negative and statistically significant, and INTERACT is not statistically significant. This finding means that firms can increase their value both by increasing their cash balances in those situations when they are below-optimal cash level and by reducing their investment in liquid assets if they are above-optimal.

Finally, the results are strongly consistent with the hypothesis when using the three different proxies for firm value. All in all, a quadratic relationship between cash holdings and firm value emerges and deviations from optimal cash holdings (above and below the optimal level) significantly reduce firm value.

\section{CONCLUSION}

The aim of this paper was to test the effect of cash holding on firm value. The paper studies a sample of 472 US industrial firms with panel data from 2001-2007. The study first empirically tests for the existence of an optimum cash level that maximizes 
firm value. Secondly, the research analyzes whether deviations from the optimum cash level reduce firm value.

The availability of internal funds is beneficial in undertaking projects without raising external capital at high transaction costs. Corporate cash holdings may reduce cash flow uncertainty, whereas the free cash flow theory argues that the free cash flow implies agency cost of managerial discretion and opportunity cost. The two effects result in the directly opposite expectation concerning the influence of cash holdings on firm value.

The study attempts to separate these two effects to some extent by considering a non linear relationship, Cash-Value. The study's findings provide substantial support for the tradeoff theory. The tradeoff theory suggests the existence of an optimum cash level which results from weighting its marginal benefits and costs. The results confirm the existence of a level of cash holding which maximizes firm value. This level varies depending on firm specifics like growth potential, access to capital markets, size, and leverage. Deviations from the optimum level reduce firm value. Hence, the management of firm liquidity is an important element and one that affects shareholder value. 


\section{REFERENCES}

Arellano M, Bond S R, 1991. Some tests of specification for panel dataMonte Carlo evidence and an application to employment equations. Review of Economic Studies 58, 277-297.

Cao C, Simin L, Zhao J, 2008. Can growth explain the trend in idiosyncratic risk?. Review of financial studies 26, 2599-2633.

Chung K H, Pruitt SW, 1994. A simple approximations of Tobin's Q. Financial Management 23, 70-74.

DeAngelo H, DeAngelo L, 2007. Capital Structure, Payout Policy, and Financial Flexibility. University of Southern California working paper.

Demsetz H, Villalonga B, 2001. Ownership structure and corporate performance, Journal of Corporate Finance 7, 209-233.

Dittmar A, Marth-Smith J, 2007. Corporate governance and the value of cash holdings. Journal of Financial Economics 83, 599-634.

Dittmar A, Marth-Smith J, and Servaes H, 2003. International Corporate Governance and Corporate Cash Holdings. Journal of Financial and Quantitative Analysis $38,111-133$.

Drobetz W, Grüninger M, Hirschvogl, 2009. Information asymmetry and the value of cash, FMA conference, Turin. 
Faulkender M, Wang R, 2006. Corporate Financial Policy and the Value of Cash. The Journal of Finance 4, 1957-1990.

Ferreira M A, Vilela A S, 2004. Why Do Firms Hold Cash? Evidence from EMU Countries. European Financial Management 10, 295-319.

Garcia-Teruel P J, Martinez-Solano P, 2008. On antecedents of SME Cash Holdings: Evidence from Spain. Journal of Business Finance \& Accounting 35, 127-149.

Himmelberg C, Hubbard R, Palia D, 1999. Understanding antecedents of managerial ownership and the link between ownership and performance. Journal of Financial Economics 53, 353-384.

Jensen M, 1986. Agency costs of free cash flow, corporate finance, and takeovers. American Economic Review 76, 323-329.

Jensen MC, Meckling W, 1976. Theory of the firm: managerial behavior, agency costs and ownership structure. Journal of Financial Economics 3, 305-360.

Keynes JM, 1936. The general theory of employment, interest and money. Mc Millan, London.

Kim CS, Mauer DC, Sherman A E, 1998. Antecedents of corporate liquidity: theory and evidence. Journal of Financial and Quantitative Analysis 33, 305-334.

McConnell JJ, Servaes H, Lins KV, 2008. Changes in insider ownership and changes in the market value of the firm. Journal of Corporate Finance 14, 92-106.

McConnell JJ, Servaes H, 1990. Additional evidence on equity ownership and corporate value. Journal of financial Economics 27, 595-613. 
Morck R, Shleifer A, Vishny R, 1988. Management ownership and market valuation: An empirical analysis. Journal of Financial Economics 20, 293-315.

Myers SC, 1977. Determinants of Corporate Borrowing. Journal of Financial Economics 5, 147-175.

Myers S, Majluf N, 1984. Corporate financing and investment decisions when firms have information that investors do not have. Journal of Financial Economics 12, $187-221$.

Lewellen W G, Badrinath S G , 1997. On the measurement of Tobin's q. Journal of Financial Economics, 40, 77-122.

Lin C, Su D, 2008. Industrial diversification, partial privatization and firm valuation: Evidence from publicly listed firms in China. Journal of Corporate Finance 14, 405-417.

Opler T, Pinkowitz L, Stulz R, Williamson R, 1999. Antecedents and implications of cash holdings. Journal of Financial Economics 52, 3-46.

Opler T, Pinkowitz L, Stulz R, Williamson R, 2001. Corporate Cash Holdings. Journal of Applied Corporate Finance 14, 55-67.

Ozkan A, Ozkan N, 2004. Corporate cash holdings: an empirical investigation of UK companies. Journal of Banking and Finance 28, 2103-2134.

Pinkowitz L, Stulz R, Williamson R, 2006. Does the contribution of corporate cash holdings and dividends to firm value depend on governance? A cross-country analysis. Journal of Finance 61, 2725-2751. 
Pinkowitz L, Williamson R, 2007. What is the market value of a dollar of Corporate Cash? Journal of Applied Corporate Finance 19, 74-81.

Pinkowitz L, Williamson R, 2001. Bank Power and Cash Holdings: Evidence from Japan. The Review of Financial Studies 14, 1059-1082.

Shin H, Stulz R, 2000. Firm value, risk, and growth opportunities. SSRN Working paper.

Stiglitz J, 1974. On the Irrelevance of Corporate Financial Policy. American Economic Review 64, 851-866.

Tong Z, 2008. Deviations from optimal CEO ownership and firm value. Journal of Banking \& Finance 32, 2462-2470.

Tong Z, 2009. Firm diversification and the value of corporate cash holdings. Journal of Corporate Finance, forthcoming. 


\section{Appendix A}

\section{Antecedents of Cash Holding}

\begin{tabular}{lc}
\hline & CASH \\
\hline CFLOW & $0.0080^{* * * *}$ \\
LIQ & $(8.30)$ \\
LEV & $-0.1542^{* * *}$ \\
& $(-7.52)$ \\
BANKD & $-0.0030^{* * * *}$ \\
& $(-19.25)$ \\
INTANGIBLE & $0.0364^{* * *}$ \\
& $(2.71)$ \\
SIZE & $-0.3672^{* * *}$ \\
& $(-12.66)$ \\
$m_{2}$ & -0.0286 \\
Hansen test (df) & $(-5.49)$ \\
p-value Hansen test & 0.155 \\
Wald test (df) & $143.92(120)$ \\
p-value Wald test & 0.068 \\
\end{tabular}

The dependent variable is CASH, which is the ratio of cash and cash equivalents to total assets. Independent variables are CFLOW, earnings after tax plus depreciation divided by gross sales; liq, defined as working capital less total cash and short term investment to total assets; lev, total liabilities and debt divided by shareholders' equity; size, natural logarithm of gross sales; BANKD, ratio of bank loans to total debt; and INTANGIBLE, intangible assets to total assets. Time dummies are included in all regressions. t statistics in brackets. ***significant at $1 \%, * *$ significant at $5 \%$, *significant at $10 \%$ level. $m 2$ is a test statistic for second order autocorrelations in residuals, distributed as standard normal $\mathrm{N}(0,1)$ under the null hypothesis of no serial correlation. Hansen test is a test of overidentifying restrictions, distributed as chi-square under the null of instrument validity. Wald Test tests the joint significance of estimated coefficients asymptotically distributed as chi-square (df) under the null of no relationship. 
Table 1

Descriptive Statistics

\begin{tabular}{ccccccc}
\hline Variable & Obs & Mean & Std. Dev. & Median & perc 10 & perc 90 \\
\hline Q & 3055 & 1.3 & 0.8 & 1.03 & 0.69 & 2.04 \\
MKBOOK1 & 3055 & 1.6 & 0.9 & 1.30 & 0.91 & 2.49 \\
MKBOOK2 & 3055 & 2.7 & 12.4 & 1.74 & 0.77 & 4.22 \\
CASH & 3055 & 0.1 & 0.1 & 0.04 & 0.01 & 0.20 \\
INTANGIBLE & 3055 & 0.2 & 0.2 & 0.13 & 0.02 & 0.40 \\
SIZE & 3055 & 13.3 & 2.1 & 13.36 & 10.45 & 15.99 \\
LEV & 3055 & 1.9 & 4.0 & 1.20 & 0.36 & 3.46 \\
\hline
\end{tabular}

The variables are the followings: ratio of the firm's market value to the replacement cost of its assets $(\mathrm{Q})$, ratio market value of firm to total assets (MKBOOK1), ratio between market capitalisation to equity book value (MKBOOK2), ratio of cash and cash equivalents to total assets (CASH), ratio of intangibles to total assets (INTANGIBLE), natural logarithm of gross sales (SIZE) and ratio of total liabilities and debt to shareholders' equity (LEV). 
Table 2

Correlation Matrix

\begin{tabular}{ccccccc}
\hline & $\mathbf{Q}$ & MKBOOK1 & MKBOOK2 & CASH & INTANGIBLE & SIZE \\
\hline $\mathbf{Q}$ & 1.00 & & & & & \\
MKBOOK1 & $0.96^{* * *}$ & 1.00 & & & & \\
MKBOOK2 & $0.25^{* * *}$ & $0.26^{* * *}$ & 1.00 & & & \\
CASH & $0.29^{* * *}$ & $0.28^{* * *}$ & 0.02 & 1.00 & & \\
INTANGIBLE & -0.02 & $-0.06^{* * *}$ & -0.01 & $-0.12^{* * * *}$ & 1.00 & \\
SIZE & $-0.08^{* * *}$ & $-0.06^{* * * *}$ & $-0.03^{*}$ & $-0.24^{* * *}$ & $0.11^{* * * *}$ & 1.00 \\
LEV & 0.01 & -0.00 & $0.60^{* * *}$ & $-0.10^{* * *}$ & $-0.04^{* *}$ & $0.08^{* * *}$ \\
\hline
\end{tabular}

The variables are the following: ratio of the firm's market value to the replacement cost of its assets (Q), ratio market value of firm to total assets (MKBOOK1), ratio between market capitalisation to equity book value (MKBOOK2), ratio of cash and cash equivalents to total assets (CASH), ratio of intangibles to total assets (INTANGIBLE), natural logarithm of gross sales (SIZE) and ratio of total liabilities and debt to shareholders 'equity (LEV).

$* * *$ significant at $1 \%, * *$ significant at $5 \%, *$ significant at $10 \%$ level 
Table 3

Corporate cash holdings and firm value

\begin{tabular}{lccc}
\hline & $\mathbf{Q}$ & MKBOOK1 & MKBOOK2 \\
& $\mathbf{( 1 )}$ & $(\mathbf{2})$ & $\mathbf{( 3 )}$ \\
\hline CASH & $0.8201^{* * * *}$ & $2.0894^{* * * *}$ & $16.6872^{* * *}$ \\
& $(2.78)$ & $(6.3)$ & $(4.92)$ \\
CASH $^{2}$ & $-2.9694^{* * *}$ & $-5.2281^{* * *}$ & $-56.3101^{* * *}$ \\
& $(-7.33)$ & $(-10.64)$ & $(-9.97)$ \\
INTANGIBLE & $-2.5613^{* * *}$ & -0.2019 & $-12.4402^{* * *}$ \\
& $(-5.43)$ & $(-0.43)$ & $(-1.97)$ \\
SIZE & -0.0019 & $-0.2669^{* * *}$ & $-2.0171^{*}$ \\
& $(-0.02)$ & $(-2.31)$ & $(-1.84)$ \\
LEV & $0.0118^{* * *}$ & $0.0133^{* * *}$ & $2.7802^{* * *}$ \\
& $(5.55)$ & $(5.51)$ & $(13.2)$ \\
$m_{2}$ & 0.962 & 0.795 & 0.197 \\
Hansen test (df) & $76.57(58)$ & $69.42(58)$ & $54.42(58)$ \\
p-value Hansen test & 0.052 & 0.145 & 0.609
\end{tabular}

In column (1) the dependent variable is Q (Tobin's Q). In column (2) the dependent variable employed to proxy firm valuation is MKBOOK1, which is market value of firm to total assets. In column (3) the dependent variable is MKBOOK2, which is the ratio of market capitalisation to equity book value. CASH and $\mathrm{CASH}^{2}$ measure cash holding. Control variables are INTANGIBLE, SIZE, and LEV. Time dummies are included in all regressions

t statistics in brackets. $* * *$ significant at $1 \%, * *$ significant at $5 \%, *$ significant at $10 \%$ level.

$m_{2}$ is test statistic for second order autocorrelations in residuals. Hansen test is a test of overidentifying restrictions. 
Table 5

Deviation from the optimal cash level and firm value (II)

\begin{tabular}{lccc}
\hline & $\mathbf{Q}$ & MKBOOK1 & MKBOOK2 \\
\hline DEVIATION & $-1.2754^{* * *}$ & $(\mathbf{2})$ & $\mathbf{( 3 )}$ \\
INTERACT & $(-2.96)$ & $-2.8190^{* * * *}$ & $-13.5508^{* * *}$ \\
& $0.8228^{* *}$ & $(-6.4)$ & $(-3.13)$ \\
INTANGIBLE & $(2.03)$ & $2.3083^{* * *}$ & -4.1597 \\
& $-3.1352^{* * *}$ & $(4.74)$ & $(-0.79)$ \\
SIZE & $(-8.31)$ & $-1.6044^{* * *}$ & $-20.1820^{* * *}$ \\
& -0.1123 & $(-3.67)$ & $(-5.66)$ \\
LEV & $(-1.59)$ & $-0.3720^{* * *}$ & $-2.6427^{* * *}$ \\
& $0.0168^{* * *}$ & $(-4.84)$ & $(-4.45)$ \\
$m_{2}$ & $(6.65)$ & $0.0192^{* * *}$ & $2.7967^{* * *}$ \\
Hansen test (df) & 0.871 & $(5.95)$ & $(19.18)$ \\
p-value & $122.49(101)$ & $122.01(101)$ & 0.293 \\
Hansen test & 0.072 & 0.076 & $106.19(101)$ \\
F-test (p-value) & $3.22(0.0727)$ & $3.27(0.0707)$ & $95.66(0.0000)$ \\
\hline In
\end{tabular}

In column (1) the dependent variable is Q (Tobin's Q). In column (2) the dependent variable employed to proxy firm valuation is MKBOOK1, which is market value of firm to total assets. In column (3) the dependent variable is MKBOOK2, which is the ratio of market capitalisation to equity book value. DEVIATION is the absolute value of residuals from optimal cash holding level regression. INTERACT is Aboveoptimal*DEVIATION where Above-Optimal is a dummy variable that takes 1 for positive residuals and 0 otherwise. Control variables are INTANGIBLE, SIZE, and LEV. Time dummies are included in all regressions.

t statistics in brackets. $* * *$ significant at $1 \%, * *$ significant at $5 \%, *$ significant at $10 \%$ level.

$m_{2}$ is test statistic for second order autocorrelations in residuals. Hansen test is a test of overidentifying restrictions. F-test refers to an $\mathrm{F}$ test on the null hypothesis that the sum of the coefficients of deviation and interact is zero. The p-value is noted in the brackets. 